This report, emphasizing a possible complication of en bloc resections involving the vertebral bodies, especially after chemotherapy, radiotherapy, or both, might prompt the thoracic surgeon to evaluate a possible solution of continuity of the dura mater during extended lung resections.

\section{References}

1. Luketich JD, van Raemdonck DE, Ginsberg RJ. Extended resection for higher-stage non-small-cell lung cancer. World J Surg. 1993;17(6):719-28.

2. Pairolero PC. Extended resections for lung cancer. How far is too far? Eur J Cardiothorac Surg. 1999;16(suppl 1):S48-50.

3. Bardet E, Moro-Sibilot D, Le Chevalier T, Massard G, Douillard JY, Theobald S, et al. Standards, options and recommendations for the management of locally advanced non small cell lung carcinoma. Bull Cancer. 2001;88(4):369-87.
4. Van Zandwijk N. Neoadjuvant strategies for non-small cell lung cancer. Lung Cancer. 2001;34(suppl 2):S145-50.

5. Non-Small Cell Lung Cancer Collaborative Group. Chemotherapy in non-small cell lung cancer: a meta-analysis using updated data on individual patients from 52 randomised clinical trials. BMJ. 1995;311: 899-909.

6. Meko J, Rusch VW. Neoadjuvant therapy and surgical resection for locally advanced non-small cell lung cancer. Semin Radiat Oncol. 2000;10(4):324-32.

7. Fowler WC, Langer CJ, Curran WJ, Keller ST. Post-operative complications after combined neo-adjuvant treatment of lung cancer. Ann Thorac Surg. 1993;55:986-9.

8. Bayo Poleo R, Jimeno Torres B, Antona Diaz M, Fernandez de Alarcon L. Traumatic disseminated pneumoencephalus. Rev Clin Esp. 1998; 198(1):45-6.

9. Saxena S, Ambesh SP, Saxena HN, Kumar R. Pneumoencephalus and convulsions after ventriculoscopy: a potentially catastrophic complication. J Neurosurg Anesthesiol. 1999;11(3):200-2.

\title{
Rupture of a chronic expanding hematoma of the thorax into lung parenchyma
}

\author{
Kenichi Okubo, MD, Toshihiro Okamoto, MD, Jun Isobe, MD, and Yoichiro Ueno, MD, Gifu, Japan
}

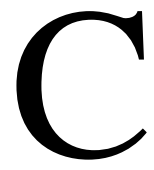

hronic expanding hematoma of the thorax is a rare entity and usually identified with mediastinal compression or chest wall protrusion in patients with a history of thoracotomy, tuberculous pleurisy, or thoracic trauma. We present a patient with chronic expanding hematoma of the thorax who had a massive hemoptysis caused by rupture into lung parenchyma.

\section{Clinical Summary}

A 59-year-old woman with a history of thoracoplasty, which included resection of the 9 th to 11 th ribs for tuberculous empyema 24 years earlier, presented with a massive hemoptysis and dyspnea. She had had a chest wall protrusion pointed out for 4 months. She was brought to our hospital by ambulance, and chest roentgenography showed bilateral lung opacity. The chest roentgenogram 2 months before showed a right intrathoracic mass-like shadow with pleural calcification (Figure 1). Because of the repet-

\footnotetext{
From the Department of General Thoracic Surgery, Gifu National Hospital, Gifu, Japan.

Received for publication Nov 4, 2003; accepted for publication Dec 15, 2003.

Address for reprints: Kenichi Okubo, MD, General Thoracic Surgery, Gifu National Hospital, Japan, 5-1-1 Hinohigashi, Gifu 500-8718, Japan (E-mail: okubo@gifu.hosp.go.jp).

J Thorac Cardiovasc Surg 2004;127:1838-40

$0022-5223 / \$ 30.00$

Copyright $\odot 2004$ by The American Association for Thoracic Surgery

doi:10.1016/j.jtcvs.2003.12.042
}

itive hemoptysis and the progression of cyanosis, emergency tracheal intubation was done to secure the airway. The bleeding was suspected from the right middle or lower lobe, and the right bronchus intermedius was blocked with a balloon within an endotracheal tube (Univent; Fuji System Corp, Tokyo, Japan). Computed tomography showed a heterogenous mass in the right thorax protruding into the chest wall and the right lung (Figure 2). The left lung was also opacified with infiltrate, indicating contralateral spread of the bleeding. Urgent bronchial arteriography was performed; the dilated bronchial artery and intercostal arteries were embolized with platinum coils and gelatin (Spongel; Yomanouchi Co, Tokyo, Japan). Despite the arterial embolization, hemostasis was not obtained immediately, and the balloon was kept inflated until the next day. Six days later, when the left infiltrate improved, the patient underwent a right pneumonectomy through a median sternotomy. Fresh hematoma was identified within the chronic organized hematoma in the thorax and penetrated into the right lung parenchyma. All the hematoma was extirpated along with pneumonectomy. Operating time was 315 minutes, and blood loss was $2077 \mathrm{~mL}$.

Postoperatively, the patient required ventilatory support for respiratory failure. After 6 days of ventilatory support, she was weaned from the respirator. After respiratory rehabilitation, she was discharged from the hospital on postoperative day 43. She has been doing well and has been free from any symptoms of the disease for $3 \frac{1}{2}$ years.

\section{Discussion}

Chronic expanding hematoma of the thorax is a rare entity. Affected patients typically have a history of medical or surgical therapy for tuberculosis. Since Iuchi and associates ${ }^{1}$ reported 5 

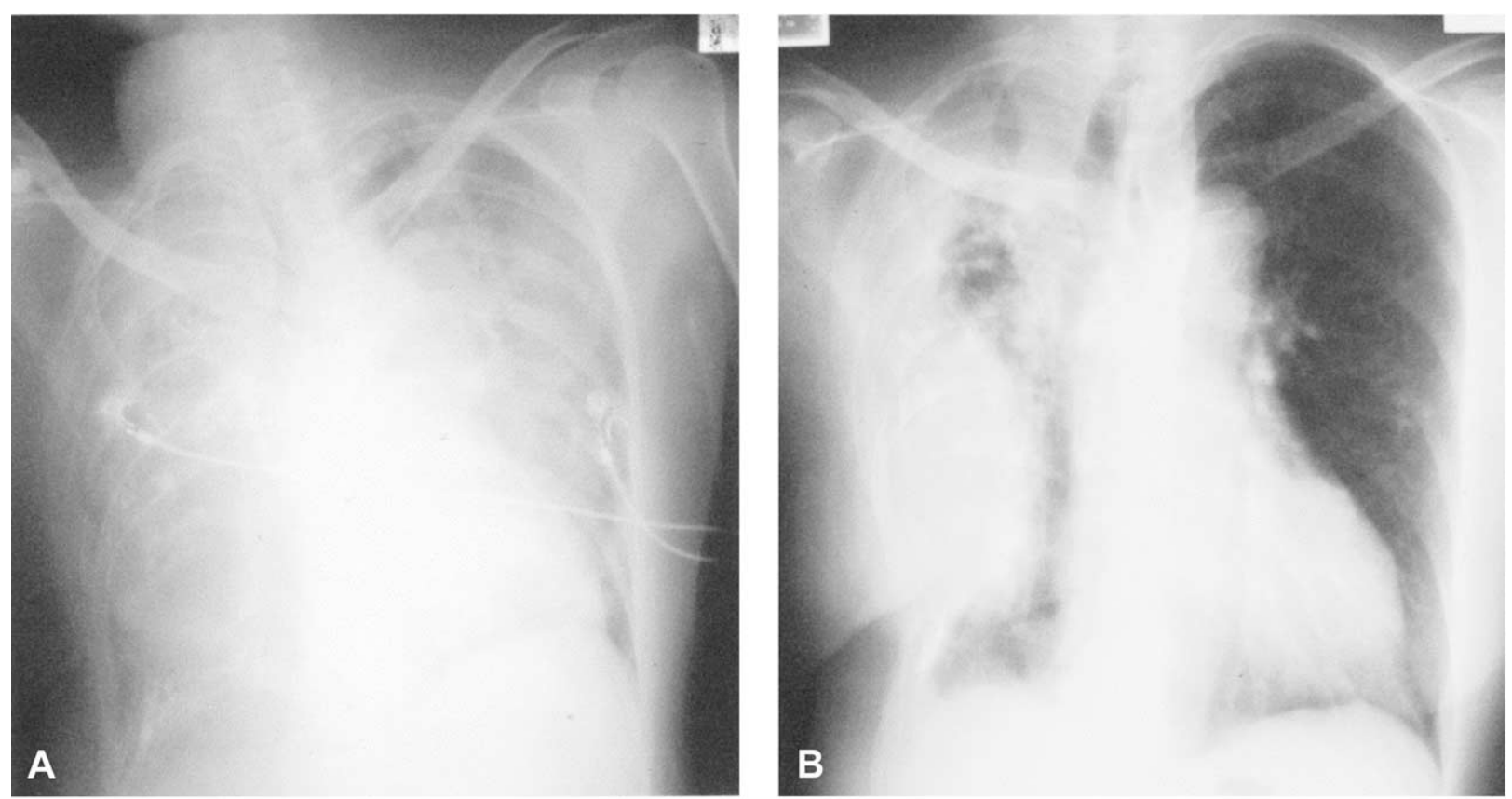

Figure 1. A, Chest roentgenogram on admission showing bilateral opacity of the lung. B, Chest roentgenogram 2 months earlier showing a mass-like lesion in the right thorax with pleural calcification and chest deformity.
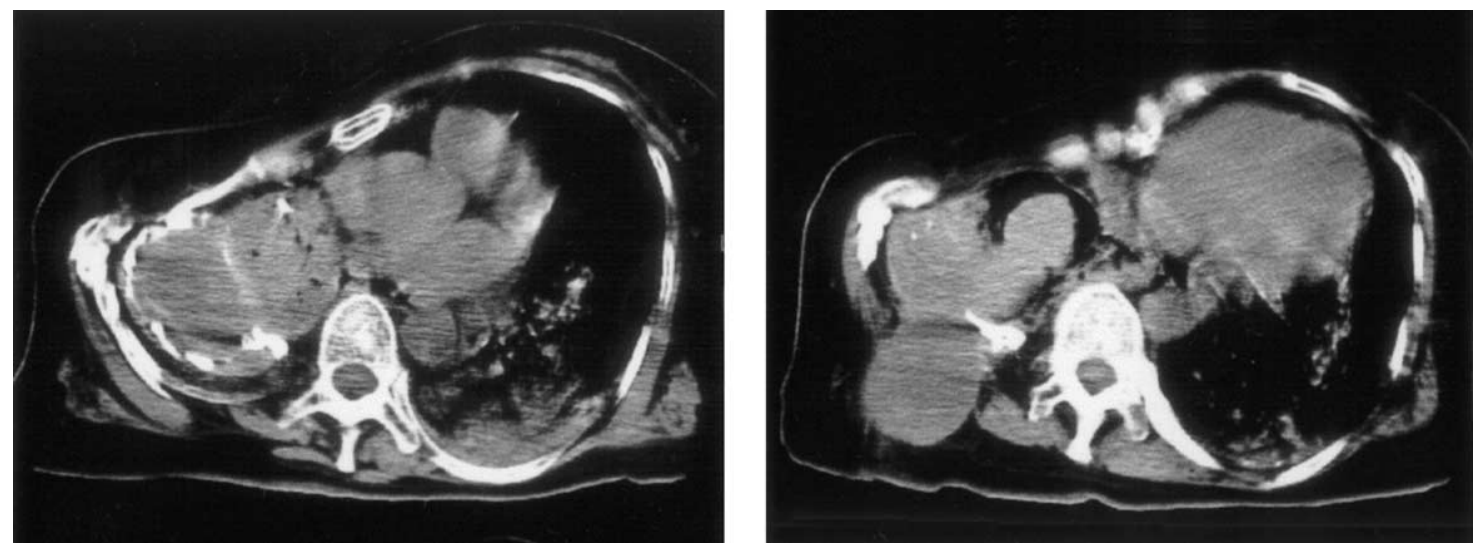

Figure 2. Chest computed tomography on admission demonstrating a heterogeneous mass in the right thorax protruding into the chest wall and right lung.

cases of empyema without pus as organized empyema in 1988, most reports of chronic expanding hematoma of the thorax have been from Japan. ${ }^{2}$ Recent literature from the United States ${ }^{3,4}$ indicates a certain incidence of chronic expanding hematoma of the thorax in western countries.

Despite the rare entity arising from the thorax, chronic expanding hematomas occur in many locations. Although most hematomas resolve spontaneously, a few persist for long periods as slowly expanding space-occupying masses. ${ }^{5}$ The pathogenesis of chronic expanding hematoma is poorly understood. Labadie and Glover ${ }^{6}$ theorized that this self-perpetuating expanding process is due to the irritant effects of blood and its breakdown products, which cause repeated exudation or bleeding from capillaries in the granulation tissue. Clinically, intermittent episodes of bleeding, probably caused by respiratory motion and coughing, might cause a progressive increase in the volume of hematoma.

The presenting symptom is usually dyspnea related to lung compression or a slowly growing chest wall mass, both of which develop even 30 years or more after thoracotomy for tuberculosis or trauma. These lesions are frequently thought to represent soft tissue sarcoma or other malignant tumors. Surgical procedure has been controversial. Palliative procedures, such as curetting or removal of the inner substance without whole-capsule excision, are reported as a result of the difficulty of the procedure or for fear of 
possible complications. However, incomplete resection of the hematoma resulted in uncontrollable bleeding from the subcapsular lesion or recurrence of hematoma within several years in some publications. ${ }^{2,7}$ Complete extirpation, including the capsule, would be desired for cure.

In our patient acute massive hemoptysis was treated with emergency tracheal intubation, balloon occlusion of the bleeding bronchus, and bronchial artery embolization. In the literature neither massive hemoptysis nor emergency management for chronic expanding hematoma of the thorax has been reported. Because the bleeding spread to the contralateral lung, the operation was intentionally delayed until the remaining lung function recovered. Thereafter, the patient successfully underwent a pneumonectomy with extirpation of the hematoma. Division of the hilum first and sequential distal dissection of the lung and hematoma through a median sternotomy might have worked well for bleeding control.

\section{References}

1. Iuchi K, Inada K, Yamamoto M, Ichimiya A, Tada H, Mori T, et al. Analysis of the empyema without pus (organized empyema). Jpn Chest Surg. 1998;2-11-7.

2. Hanagiri T, Muranaka H, Hoshimoto M, Nishio T, Sakai S, Ono M, et al. Chronic expanding hematoma in the chest. Ann Thorac Surg. 1997; 64:559-61.

3. Roper CL, Cooper JD. Chronic expanding hematoma of the thorax. J Thorac Cardiovasc Surg. 2001;122:1046-8.

4. Hwang GL, Moffatt SD, Mitchell JD, Leung AN. Chronic expanding hematoma of the thorax. AJR Am J Roentgenol. 2003;180:1182-3.

5. Reid JD, Kommareddi S, Lankerani M, Park MC. Chronic expanding hematomas. A clinicopathologic entity. JAMA. 1980;244:2441-2.

6. Labadie EL, Glover D. Physiopathogenesis of subdural hemangiomas. Part 1: Histological and biochemical comparisons of subcutaneous hematoma in rats with subdural hematoma in man. J Neurosurg. 1976;45:382-92.

7. Matsuge S, Hosokawa Y, Yamzaki S, Sato K, Murakami Y, Yamakawa $\mathrm{T}$, et al. Five cases of surgically resected chronic expanding hematoma in the chest. Jpn J Thorac Surg. 2000;53:768-73.

\title{
Thyroid metastasis after resection of atypical bronchial carcinoid
}

\author{
Pier Luigi Filosso, MD, ${ }^{\text {a } A n n a ~ A r s l a n i a n, ~ M D, ~}{ }^{a}$ Nicola Palestini, MD, ${ }^{\mathrm{b}}$ Alessandra Farnetti, MD, ${ }^{\mathrm{b}}$ Mauro Papotti, MD, ${ }^{\mathrm{c}}$ \\ Massimo Bongiovanni, MD, ${ }^{\mathrm{c}}$ Roberto Giobbe, MD, and Enrico Ruffini, MD, ${ }^{a}$ Torino, Italy
}

B ronchial carcinoids $(\mathrm{BCs})$ are rare and constitute less than $2 \%$ of pulmonary tumors. ${ }^{1}$ They are characterized by slow, mainly endobronchial growth, with infrequent regional lymph node involvement or distant metastases. ${ }^{2}$ Atypical carcinoids are part of the spectrum of neuroendocrine bronchopulmonary tumors, according to the 1999 World Health Organization-International Association for the Study of Lung Cancer (WHO-IASLC) Lung Tumor classification. ${ }^{3}$ They present 2 low-grade (typical and atypical carcinoids) and 2 high-grade malignant varieties (large cell neuroendocrine carcinoma and small cell lung carcinoma), the latter characterized by a high tendency toward mediastinal and distant metastatic spread.

Among low-grade malignant tumors, atypical carcinoids show a more aggressive biologic behavior than typical carcinoids ${ }^{4}$ : mediastinal lymph node metastases occur at presentation in about $15 \%$ of cases. Distant metastases are generally in the liver and in the bone.

From the Department of Thoracic Surgery, Division of General Surgery, and the Department of Human Oncology and Biomedical Sciences, University of Torino, Torino, Italy.

Received for publication Feb 11, 2003; accepted for publication March 12, 2003.

Address for reprints: Pier Luigi Filosso, MD, University of Torino, San Giovanni Battista Hospital, Via Genova, 3, Torino 10126, Italy (E-mail: pierluigifilosso@tiscalinet.it).

J Thorac Cardiovasc Surg 2004;127:1840-3

$0022-5223 / \$ 30.00$

Copyright $\odot 2004$ by The American Association for Thoracic Surgery

doi:10.1016/j.jtcvs.2003.03.005
We present a case of a woman in whom thyroid metastasis occurred 30 months after the resection of an atypical BC.

\section{Clinical Summary}

A 53-year-old white woman was referred to us in June 1999 because of the presence of a large pulmonary mass $(7 \times 3 \mathrm{~cm}$ in size) in the right lower lobe. The lesion had been detected with chest radiography performed in July 1998, and it was $5 \times 2 \mathrm{~cm}$ in size, but at that time, the patient refused the intervention. She eventually agreed to be operated on because of the progression of the lesion and the associated cough and dyspnea. A preoperative transthoracic fine-needle aspiration biopsy was performed, and neoplastic cells with neuroendocrine features were observed. ${ }^{111}$ In-DTPA-Pentetreotide scintigraphy (Octreoscan) was performed for a correct preoperative assessment, resulting in an elective uptake in correspondence of the pulmonary lesion with no other abnormal uptakes. Chromogranin A and neuron-specific enolase serum levels were performed and increased: $197 \mathrm{ng} / \mathrm{mL}$ (normal values, $20-100 \mathrm{ng} / \mathrm{mL}$ ) and $62 \mathrm{ng} / \mathrm{mL}$ (normal values, $<12.5 \mathrm{ng} / \mathrm{mL}$ ), respectively.

The patient underwent a right pneumonectomy with systemic lymphadenectomy: a more conservative intervention was not possible because of the tumor size. A residual tumor was left on the inferior pulmonary vein stump.

Grossly, an 8-cm mass with poorly demarcated borders infiltrating the mediastinal pleura and the adipose mediastinal tissue was found. The cut surface was tan-yellow, and a brown lymph node was adherent and directly infiltrated by the tumor.

Microscopically, the tumor was not capsulated, and it had a uniform organoid growth pattern composed of nests and sheets of cuboidal and eosinophilic cells. Rosette-like structures were also 